\title{
Hubungan index massa tubuh/umur (IMT/U) dengan crowding Anterior pada anak usia 10-12 tahun
}

\author{
Alvina Roesianto ${ }^{*}$, Winny Suwindere ${ }^{1}$, Linda Sari Sembiring ${ }^{1}$ \\ ${ }^{1}$ Departemen Ilmu Kesehatan Gigi Masyarakat, Fakultas Kedokteran Gigi, Universitas Kristen \\ Maranatha, Indonesia
}

*Korespondensi: alvinar135@gmail.com

\begin{abstract}
ABSTRAK
Pendahuluan: Gizi memiliki peranan penting dalam pertumbuhan dan perkembangan tubuh, namun gizi masih menjadi masalah utama kesehatan masyarakat di Indonesia. Kekurangan gizi terhadap seseorang memiliki dampak terhadap rongga mulutnya yaitu pertumbuhan dan perkembangan rahang yang terhambat sehingga dapat menyebabkan crowding. Penelitian ini bertujuan untuk mengetahui hubungan Indeks Massa Tubuh menurut Umur (IMT/U) dengan terjadinya crowding anterior pada anak usia 10-12 tahun pada SD Mulia Wacana Bandung. Metode: Jenis penelitian observasional-analitik dengan rancangan penelitian berupa crosssectional. Subjek penelitian berjumlah 74 anak di SD Mulia Wacana Bandung, pengambilan sampel dengan teknik purposive sampling yaitu pengambilan sampel berdasarkan kriteria inklusi dan ekslusi. Data yang dikumpulkan berupa status gizi anak berdasarkan Index Massa tubuh / Umur (IMT/U) dan keadaan susunan gigi (crowding). Analisis data menggunakan Fisher Exact Test. Pengolahan data menggunakan program SPSS. Hasil: Terdapat 8,8\% anak kategori obesitas (14\%) terdapat crowding anterior, 1,8\% anak kategori overweight $(12,3 \%)$ terdapat crowding anterior, $21,1 \%$ anak kategori normal $(36,8 \%)$ terdapat crowding anterior, dan $24,6 \%$ anak kategori kurus $(36,8 \%)$ terdapat crowding anterior dan didapatkan nilai p untuk Fisher Exact Test sebesar 0,108. Simpulan: tidak terdapat hubungan status gizi dengan Crowding Anterior.
\end{abstract}

Kata kunci: Crowding anterior, gizi, status gizi

\section{Relationship between body mass index/age (BMI/A) and crowding anterion of children aged 10-12 Years in Elementary School " $X$ "}

\section{ABSTRACT}

Introduction: Nutrition has an important role in the growth and development of the body, but nutrition remains a major public health problem in Indonesia. Lack of nutrition has an impact on the oral cavity of growth and development of the jaw that is inhibited so that it can cause crowding. The purpose of this study to determine the relationship of Body Mass Index for Age (BMI/A) with the occurrence of anterior crowding in children aged 10-12 years on SD Mulia Wacana Bandung. Method: This research is an observational-analytic research with crosssectional design. Subjects were 74 children in SD Mulia Wacana Bandung, and the sample was selected by using purposive sampling technique which is based on inclusion and exclusion criteria. The collected data consisted of nutritional status of children based on Body Mass Index for Age (BMI/A) and the state of the arrangement of teeth (crowding). Data analysis using Fisher Exact Test. Data processing using SPSS program. Results: there were 8.8\% of obese children (14\%), anterior crowding, $1.8 \%$ overweight children (12.3\%), anterior crowding, $21.1 \%$ normal category (36.8\% there was anterior crowding, and $24.6 \%$ children of thin category (36.8\%) had anterior crowding and obtained $p$ value for Fisher Exact Test of 0.108. Conclusions: show no relationship of nutritional status with Anterior Crowding.

Keywords: Anterior crowding, nutrition, nutritional status 


\section{PENDAHULUAN}

Gizi memiliki peranan penting dalam pertumbuhan dan perkembangan tubuh, namun gizi masih menjadi masalah utama kesehatan masyarakat di Indonesia. ${ }^{1}$ Status gizi merupakan kondisi kesehatan yang terkait dengan konsumsi makanan oleh tubuh dan suatu keadaan tubuh yang diakibatkan oleh keseimbangan antara asupan zat gizi dengan kebutuhan. ${ }^{2}$ Status gizi merupakan salah satu faktor yang menentukan sumber daya manusia dan kualitas hidup. ${ }^{3}$ Menurut $\mathrm{WHO}^{4}$ status gizi berdasarkan IMT/U (Indeks Massa Tubuh menurut Umur) dikategorikan menjadi sangat kurus, kurus, obesitas, overweight.

Status gizi berdasarkan IMT/U yang rendah (<-2 Standar Deviasi) merupakan pertanda dimana anak mengalami kekurangan gizi. $\mathrm{WHO}^{4}$ memperkirakan bahwa anak yang kekurangan gizi sejumlah 181,9 juta (32\%) di negara yang sedang berkembang di Asia Selatan bagian tengah dan Afrika Timur. Berdasarkan Riset Kesehatan Dasar (Riskesdas 2013) ${ }^{6}$, prevalensi gizi kurang pada balita adalah 19,6\%. Prevalensi kurus dan sangat kurus secara nasional tahun 2013 masih cukup tinggi yaitu masing-masing 12,1\% dan 5,3\%. ${ }^{6}$ Hasil penelitian dari UNICEF $^{5}$ mengatakan terdapat 16 provinsi menunjukkan prevalensi berat badan kurang pada anak sekitar $20 \%$.

Kekurangan gizi terhadap seseorang memiliki dampak terhadap rongga mulutnya yaitu pertumbuhan dan perkembangan rahang yang terhambat sehingga dapat menyebabkan crowding. ${ }^{6}$ Kurang gizi menyebabkan berkurangnya tinggi dari rahang, panjang dari dasar tengkorak dan variasi lebar maxillomandibular yang dapat mengakibatkan maloklusi terutama crowding karena kurangnya ruangan untuk gigi tumbuh ditempat yang tepat. Namun crowding juga dapat disebabkan karena kebiasaan buruk, genetik, dan gangguan pertumbuhan skeletal. ${ }^{7}$

Al-Balkhi dan Al-Zahrani ${ }^{8}$ meneliti dari 614 pasien Saudi Arabia ditemukan crowding sebesar $49,5 \%$ terutama pada regio anterior. Menurut penelitian Nur Avia9 pada tahun 2017 di Banjarbaru menunjukkan prevalensi crowding anterior sebesar 61\%. Kemudian penelitian Thomas $^{10}$ menyatakan terdapat dampak malnutrisi pada kesehatan oral, dihubungkan dengan tingginya prevalensi karies, dimana sama tingginya dengan kejadian malformasi dental dan trauma pada jaringan lunak. Kemudian ditemukannya efek secara signifikan dari malnutrisi pada pertumbuhan dan perkembangan dari tulang fasial pada anak dan perkembangan dari otot skeletal. Penelitian Staufer ${ }^{11}$ menyatakan bahwa terjadinya crowding dapat menyebabkan infraksi pada gigi, fraktur pada gigi, gangguan mastikasi, karies, gingivitis, periodontitis dan resesi gingiva. ${ }^{11}$

Resorpsi gigi sulung dan erupsi gigi permanen dimulai pada periode sekolah dari umur 6 sampai 12 tahun yang biasanya disebut sebagai periode mixed dentition. Periode sekolah dibagi menjadi 2 bagian yaitu periode sekolah awal dari usia 6-10 tahun dan periode prepubertal dari usia 10 hingga 12 tahun yang merupakan akhir dari periode mixed dentition. Dimana proses pertumbuhan akan berlangsung sampai umur 12 tahun dan gigi anterior permanen telah erupsi seluruhnya sehingga dapat mengamati crowding secara keseluruhan pada gigi permanen anterior. $^{12}$

Hasil penelitian Brito et al. ${ }^{13}$ menyatakan lebih tingginya prevalensi crowding pada periode mixed dentiton $(26,8 \%)$ daripada periode gigi permanen $(18,7 \%)$. Pemeriksaan dini terhadap maloklusi perlu dilakukan pada masa prepubertal sehingga bila ditemui adanya maloklusi dapat dilakukan perawatan dini. ${ }^{14}$ Anak pada periode usia mixed dentition juga sering mengalami kurangnya gizi karena mengingat bertambahnya berat badan dan aktivitasnya sehingga membutuhkan gizi dengan porsi lebih banyak. Tetapi adakalanya mereka lebih suka makan di kantin, terpengaruh oleh lingkungannya sehingga mengakibatkan gizinya kurang. ${ }^{15,16}$

Status gizi yang kurang dapat juga dipengaruhi oleh sosial ekonomi yang buruk. Sekolah Dasar Mulia Wacana merupakan sekolah swasta yang rata-rata siswanya berada pada tingkatan sosial ekonomi menengah ke bawah sehingga mengakibatkan daya beli yang kurang yang dapat mempengaruhi asupan makanan pada anak, hal ini telah dilakukan observasi sebelumnya dimana iuran uang sekolah setiap anak ditentukan sesuai kemampuan ekonomi orang tuanya dan tidak ditentukan oleh sekolah tersebut.

Uraian tersebut diatas mendorong untuk meneliti dengan tujuan penelitian untuk menganalisis hubungan antara Indeks Massa Tubuh menurut Umur (IMT/U) dengan crowding anterior pada anak. Peneliti akan melakukan penelitian pada anak usia 
10 hingga 12 tahun. Penelitian ini dilakukan pada SD Mulia Wacana dengan tingkat sosial ekonomi yang menengah kebawah.

\section{METODE}

Jenis penelitian observasional-analitik dengan rancangan penelitian berupa cross- sectional. Subjek penelitian berjumlah 74 anak di SD Mulia Wacana Bandung. Teknik pengambilan sampel penelitian ini adalah Purposive Sampling yang artinya sampel diambil berdasarkan kriteria tertentu oleh peneliti yaitu kriteria inklusi dan eksklusi. ${ }^{17}$ Kriteria inklusi adalah anak usia 10-12 tahun yang bersekolah di SD Mulia Wacana (sudah melewati ulang tahun ke-10 dan belum melewati ulang tahun ke-12), Orang Tua bersedia mengisi kuisioner tentang asupan nutrisi pada anak, gigi anterior permanen sudah erupsi Kriteria eksklusi adalah anak yang tidak kooperatif, anak yang mengalami agenesis dan anak yang mengalami persistensi.

Variabel Penelitian yaitu variabel bebas pada penelitian ini status gizi pada anak. Variabel terikat adalah crowding anterior dan variabel penganggu adalah jenis kelamin dan faktor penyebab crowding lain selain nutrisi (genetik, supernumerary teeth). Alat yang digunakan antara lain kertas kuesioner, alat tulis, alat dasar (sonde, kaca mulut, ekskavator, dan pinset), masker, handscoen, senter, kotak steril, height and weight scales, kalkulator, check retractor, dan kamera.Bahan yang digunakan antara lain air untuk berkumur dan membersihkan alat, alkohol, dan tissue.

Langkah kerja penelitian yaitu pertama mengurus perijinan penelitian ke sekolah SD Mulia Wacana Bandung, lalu mengurus persetujuan dari komisi etik penelitian Fakultas Kedokteran Universitas Kristen Maranatha Rumah Sakit Immanuel, mempersiapkan kuesioner yang akan digunakan dalam penelitian dengan dilakukan uji validitas dan realibilitas. Mengatur jadwal dilaksanakannya survei untuk pemeriksaan rongga mulut, mempersiapkan alat yang akan digunakan pada saat penelitian, memberikan informasi tertulis mengenai prosedur penelitian kepada orang tua dan guru lalu meminta persetujuan orang tua untuk kesediaan putra putrinya untuk menjalani prosedur penelitian dengan diminta untuk menandatangani informed consent.
Langkah kedua, menghitung berat badan dan tinggi badan anak dengan height and weight scale, mengkalkulasi pengukuran status gizi berdasarkan Index Massa Tubuh/Umur (IMT/U) menggunakan tabel WHO, kemudian dilakukan pemeriksaan rongga mulut dengan menggunakan check retractor lalu dilakukan pengambilan gambar pada bagian gigi anterior rahang atas dan rahang bawah, lalu melakukan pengolahan dan perhitungan data yang telah didapatkan pada saat penelitian. Data hasil kuisioner dan hasil pemeriksaan yang diperoleh akan diolah menggunakan perangkat lunak komputer SPSS. Analisis data yang digunakan menggunakan korelasi Chi Square namun apabila nilai harapan dari sel pada tabel ada yang $<5$ maka menggunakan Fisher Exact Test yang merupakan korelasi antara Index Massa Tubuh / Umur (IMT/U) dan crowding anterior

\section{HASIL}

Penelitian dilakukan pada 74 subjek penelitian yang berusia 10-12 tahun di Sekolah Dasar Mulia Wacana Bandung. Berdasarkan kriteria inklusi yang ditetapkan terdapat 57 anak yang masuk dalam kriteria penelitian yaitu anak yang berusia 10 hingga 12 tahun dan gigi permanen anterior telah erupsi pada SD Mulia Wacana Bandung, kemudian dilakukan penghitungan berat badan, tinggi badan, dan dilakukan observasi terhadap gigi anterior rahang atas dan bawah pada anak. Tabel 1 menunjukkan berat badan, tinggi badan, index massa tubuh, dan umur pada 57 sampel.

Tabel 1 Berat Badan, Tinggi Badan, dan IMT

\begin{tabular}{|c|c|c|c|c|c|}
\hline & $\mathbf{N}$ & Min & Max & & Std. \\
\hline & & Mean & & & Deviation \\
\hline Berat Badan & 57 & 21 & 62 & 35,3947 & 9,90794 \\
\hline $\begin{array}{l}\text { Tinggi Badan } \\
\text { (cm) }\end{array}$ & 57 & 122,5 & 161 & 141,781 & 8,53565 \\
\hline $\begin{array}{c}\text { Index Massa } \\
\text { tubuh }\end{array}$ & 57 & 11,9 & 27 & 17,2905 & 3,53146 \\
\hline Umur & 57 & 10 & 12 & 10,6316 & 0,67166 \\
\hline $\begin{array}{c}\text { Valid N } \\
\text { (listwise) }\end{array}$ & 57 & & & & \\
\hline
\end{tabular}

Tabel di atas menggambarkan data responden berdasarkan kategori Umur. Berdasarkan tabel di atas, sebanyak 29 (51\%) responden memiliki jenis kelamin laki-laki dan 28 (49\%) responden memiliki jenis kelamin perempuan. 


\begin{tabular}{|c|c|c|}
\hline & $\mathbf{F}$ & $\%$ \\
\hline \multicolumn{3}{|c|}{ Jenis Kelamin } \\
\hline Laki-laki & 29 & 51 \\
\hline Perempuan & 28 & 49 \\
\hline \multicolumn{3}{|c|}{ Umur (Tahun) } \\
\hline 10 & 27 & 47,4 \\
\hline 11 & 24 & 42,1 \\
\hline 12 & 6 & 10,5 \\
\hline Total & 57 & 100 \\
\hline \multicolumn{3}{|c|}{ Status gizi } \\
\hline Obesitas & 8 & 14 \\
\hline Overweight & 7 & 12,3 \\
\hline Normal & 21 & 36,8 \\
\hline Kurus & 21 & 36,8 \\
\hline Total & 57 & 100 \\
\hline \multicolumn{3}{|c|}{ Crowding anterior } \\
\hline Ya & 32 & 56,1 \\
\hline Tidak & 25 & 43,9 \\
\hline Total & 57 & 100 \\
\hline
\end{tabular}

Tabel 3. Hubungan status gizi dengan crowding anterior

\begin{tabular}{|c|c|c|c|c|c|}
\hline \multirow{2}{*}{ Status Gizi - } & \multicolumn{3}{|c|}{ Crowding anterior } & \multirow[t]{2}{*}{ Kota } & \multirow{3}{*}{$X^{2}$ hit $=6,065$} \\
\hline & & Ya & Tidak & & \\
\hline \multirow{2}{*}{ Obesitas } & $\mathrm{f}$ & 5 & 3 & 8 & \\
\hline & $\%$ & $8,8 \%$ & $5,3 \%$ & $14,0 \%$ & \multirow{6}{*}{$\mathrm{X} 2 \mathrm{Tab}=7,815$} \\
\hline \multirow{2}{*}{ Overweight } & $\mathrm{f}$ & 1 & 6 & 7 & \\
\hline & $\%$ & $1,8 \%$ & $10,5 \%$ & $12,3 \%$ & \\
\hline \multirow{2}{*}{ Normal } & $\mathrm{f}$ & 12 & 9 & 21 & \\
\hline & $\%$ & $21,1 \%$ & $15,8 \%$ & $36,8 \%$ & \\
\hline \multirow{3}{*}{ Kurus } & $\mathrm{f}$ & 14 & 7 & 21 & \\
\hline & $\%$ & $24,6 \%$ & $12,3 \%$ & $36,8 \%$ & \multirow{3}{*}{ Sig $=0,108$} \\
\hline & $\mathrm{f}$ & 32 & 25 & 57 & \\
\hline Total & $\%$ & $56,1 \%$ & $43,9 \%$ & $100,0 \%$ & \\
\hline
\end{tabular}

Untuk melihat hubungan antara status gizi dengan Crowding Anterior, digunakan analisis chisquare dengan hipotesis sebagai berikut: Hipotesis: Ho: Tidak terdapat hubungan antara status gizi dengan Crowding Anterior; H1: Terdapat hubungan antara status gizi dengan Crowding Anterior. Berdasarkan hasil perhitungan statistik tersebut diperoleh nilai $x^{2}$ hitung sebesar $(6,065)$. Hasil uji statistik menunjukkan bahwa $x^{2}$ hitung $(6,065)<\mathrm{x}^{2}$ tabel $(7,815)$. Oleh karena itu Ho diterima. Artinya, tidak terdapat hubungan status gizi dengan Crowding Anterior.

Tabel 3. Frekuensi anak mengkonsumsi makanan, anak membawa bekal, anak memakan daging ayam, daging sapi, dan ikan, anak makan disertai buah dan sayuran, jenis makanan selingan yang dimakan oleh anak, frekuensi anak makan makanan selingan, frekuensi anak meminum susu, frekuensi anak minum minuman kemasan, kisaran uang jajan yang dibawa anak, jenis jajanan anak

\begin{tabular}{cccc}
\hline \multirow{2}{*}{$\begin{array}{c}\text { Pertanyaan } \\
\text { Frekuensi anak mengkonsumsi makanan } \\
\text { anak }\end{array}$} & $\%$ \\
\hline \multirow{2}{*}{ Kuesioner 1} & 2X sehari & 10 & 17,5 \\
& 3X sehari & 47 & 82,5 \\
\hline \multirow{2}{*}{ Kuesioner 2} & Frekuensi anak membawa bekal & & \\
\cline { 2 - 4 } & Kadang-kadang & 1 & 1,8 \\
& Ya & 14 & 24,6 \\
\hline
\end{tabular}

Frekuensi anak memakan daging ayam, daging sapi, dan ikan

\begin{tabular}{lll}
\hline Tidak & 2 & 3,5
\end{tabular}

$\begin{array}{llll}\text { Kuesioner } 3 & \text { Kadang-kadang } & 31\end{array}$

$\begin{array}{llll}\text { Ya } & 24 & 42,1\end{array}$

\begin{tabular}{cccc}
\hline \multicolumn{4}{c}{ Frekuensi anak makan disertai buah dan sayuran } \\
\hline \multirow{2}{*}{ Kuesioner 4 } & Tidak & 1 & 1,8 \\
& Kadang-kadang & 40 & 70,2 \\
Ya & 16 & 28,1 \\
\hline \multirow{2}{*}{ Jenis makanan selingan yang dimakan oleh anak } \\
\hline \multirow{2}{*}{ Kuesioner 5 } & Permen/coklat & 3 & 5,3 \\
& Biscuit/kue/roti & 47 & 82,5 \\
& Buah & 7 & 12,3
\end{tabular}

\begin{tabular}{cccc}
\hline \multicolumn{4}{c}{ Frekuensi anak makan makanan selingan } \\
\hline \multirow{2}{*}{ Kuesioner 6 } & 3X sehar & 7 & 12,3 \\
& 3X sehar & 7 & 12,3 \\
2X sehar & 43 & 75,4 \\
\hline & Frekuensi anak meminum susu & \\
\hline \multirow{3}{*}{ Kuesioner 7 } & Tidak & 8 & 14 \\
& Kadang-kadang & 23 & 40,4 \\
& Ya & 26 & 45,6 \\
\hline
\end{tabular}

\begin{tabular}{|c|c|c|c|}
\hline \multicolumn{4}{|c|}{ Frekuensi anak minum minuman kemasan } \\
\hline \multirow{3}{*}{ Kuesioner 8} & Setiap hari & 2 & 3,5 \\
\hline & 2- $3 \mathrm{X}$ seminggu & 6 & 10,5 \\
\hline & 3 & 49 & 86 \\
\hline \multicolumn{4}{|c|}{ Kisaran uang jajan yang dibawa anak } \\
\hline \multirow{3}{*}{ Kuesioner 9} & $>4000$ & 18 & 31,6 \\
\hline & $3000-4000$ & 19 & 33,3 \\
\hline & Tidak bawa uang jajan & 20 & 35,1 \\
\hline \multicolumn{4}{|c|}{ Jenis jajanan anak } \\
\hline \multirow{4}{*}{$\begin{array}{c}\text { Kuesioner } \\
10\end{array}$} & Jenis makanan ringan & 12 & 21,1 \\
\hline & Biskuit/kue/roti & 22 & 38,6 \\
\hline & $\begin{array}{c}\text { Selalu membawa bekal dari } \\
\text { rumah }\end{array}$ & 23 & 40,4 \\
\hline & Total & 57 & 100 \\
\hline
\end{tabular}




\section{PEMBAHASAN}

Hasil penelitian pada Tabel 4 memperlihatkan tingkat prevalensi yang tinggi dari status gizi yang rendah hal ini tidak jauh berbeda dengan penelitian Sarah Salim di Jakarta dan Suharyanto di Blora pada anak Sekolah dasar 37\% dan 38,6\% anak yang status gizi rendah. Didapatkan juga dari penelitian ini prevalensi crowding anterior yang tinggi pada Tabel 5 pada seluruh tingkatan status gizi baik yang tinggi atau rendah. Hal ini serupa dengan hasil penelitian yang dilakukan oleh Brito D.I di Brazil pada anak 9-12 tahun prevalensi besar pada crowding (45,5\%).

Hasil penelitian status gizi dengan crowding anterior pada Tabel 3, menunjukkan hasil $\mathrm{p}>0,05$ bahwa tidak terdapat hubungan tingkat status gizi dengan terjadinya crowding anterior pada anak usia 10-12 tahun. Hal ini menunjukan tidak ada perbedaan yang signifikan dari setiap tingkat status gizi memiliki prevalensi crowding anterior yang tinggi. Hal ini serupa dengan penelitian yang dilakukan Thomaz dkk. $^{10}$ Pada tahun 2010 yang diteliti pada anak berusia 12-15 tahun di Brazil diperoleh hasil bahwa tidak terdapat hubungan antara gizi buruk dengan kasus gigi berjejal.

Hasil tersebut di atas diperkirakan disebabkan karena crowding memilikit etiologi yang multifaktorial, yang tidak hanya disebabkan karena status gizi yang rendah dari pengaruh asupan nutrisinya saja tetapi juga dipengaruhi oleh faktor genetik. Salah satu faktor genetikyang mempengaruhi terjadinya crowding adalah panjang lengkung rahang dan ukuran gigi, harus terdapat keharmonisan antara lengkung rahang dengan ukuran gigi.

Penelitian yang dilakukan Hamid M Waheed ${ }^{18}$ dimana orang yang mengalami crowding memilki panjang rahang yang lebih pendek dan ukuran mesiodistal gigiyang lebih lebar. Kebiasaan burukjuga dapat mengakibatkan crowding seperti menghisap jempol dan mouth breathing. Maloklusi yang terjadi dipengaruhi dari durasi, frekuensi dan seberapa besar tekanan kebiasaan buruk tersebut dilakukan. ${ }^{19}$ Peneliti Nidhi Pruthi ${ }^{20}$ menyatakan bahwa oral habbit mengakibatkan $52.7 \%$ maloklusi termasuk crowding anterior. Kemudian supernumerary teeth berakibat pada terjadinya crowding menurut Iswari $\mathrm{H}^{19}$ supernumerary teeth dapat mengakibatkan rotasi, perubahan posisi gigi, dan maloklusi.

Asupan nutrisi penting bagi pertumbuhan dan perkembangan anak. Pada Tabel 8 terdapat
$54,4 \%$ anak yang hanya kadang-kadang saja mengkonsumsi daging ayam, daging sapi, dan ikan. Tabel 9 menunjukkan 70,2\% anak hanya kadangkadang mengkonsumsi buah-buahan dan sayursayuran. Kemudian Tabel 12 memperlihatkan $40,5 \%$ anak hanya kadang- kadang saja meminum susu. Kemudian anak juga lebih memilih makanan selingan berupa biskuit atau roti dibandingkan buah-buahan yang terlihat pada Tabel 3 dan anak sering meminum minuman kemasan seperti yang ditunjukkan pada Tabel 4. Maka dari itu kebiasaan anak membawa bekal dari rumah dilihat dari Tabel 7 cukup dan seimbang.

Nutrisi yang seimbang perlu dilakukan dietary counseling berupa konsumsi daging, sayursayuran, buah-buahan, dan susu yang mengandung banyak vitamin, protein, dan mineral yang sangat menunjang bagi pertumbuhan dan perkembangan anak. Menurut USDA (The US Departement of Agriculture) menyarankan untuk mengkonsumsi sayuran sebanyak 2,5 cup (275 gram) perhari, buah-buahan 1,5 cup (165 gram) perhari, susu 750 $\mathrm{ml}$ perhari, daging 150 gram perhari dan makanan utama sebanyak 3 kali sehari.

Hal tersebut dapat diinformasikan dengan dilakukan penyuluhan pada anak, guru dan orang tua murid pada Sekolah Dasar Mulia Wacana Bandung, sehingga menjadi sadar akan pentingnya nutrisi yang cukup dan seimbang yang dapat mempengaruhi kesehatan secara keseluruhan. Secara khusus nutrisi juga mempengaruhi pertumbuhan dan perkembangan struktur oral salah satunya pertumbuhan rahang yang dapat mempengaruhi terjadinya crowding. Kelemahan dalam penelitian ini adalah pengukuran dari crowding anterior tidak diukur berdasarkan tingkatan mild, moderate, dan severe dan tidak mempertimbangkan faktor lain yang menjadi penyebab terjadinya crowding seperti genetik dan supernumerary teeth.

\section{SIMPULAN}

Tidak terdapat hubungan antara Index Massa Tubuh/ Umur (IMT/U) dengan crowding anterior pada anak usia 10-12 tahun.

\section{DAFTAR PUSTAKA}

1. Siti F, Dina PP, Natalia LD. Hubungan ketahanan tingkat keluarga dan tingkat kecukupan 
zat gizi dengan status gizi batita di Desa Gondangwinangun Tahun 2011. J Kes Masy 2013;2(2):19.

2. Cataldo CB, DeBruyne LK, Whitney EN. Nutrion and diet therapy. Wadsworth/Thomson Learning 2003.

3. Hidayatullah, Adhani R, Triawanti. Hubungan tingkat keparahan karies dengan status gizi kurang dan gizi baik tinjauan pada anak balita Di Tk Kecamatan Kertak Hanyar Kabupaten Banjar. Dentinojurnal Kedokteran Gigi 2016;1(1):104-7.

4. World Health Organisation (WHO). Word Health Statistik. Switzerland: Monitoring health for the SDGs, sustainable development goals. BMI for age (5-19 years). 2018.

5. Ringkasan Kajian. Gizi Ibu \& Anak. Jakarta: UNICEF Indonesia, Oktober 2012. h. 1-6.

6. Oktasafitri D. Hubungan status gizi dengan gigi berjejal pada murid SMP Sutomo 2 Medan. Skripsi. Fakultas Kedokteran Gigi USUS 2014.

7. Senjaya AA. Kebiasaan burukyang dapat merubah bentuk wajah. J Skal Hus 2012 April;9(1):22-7.

8. Al-Balkhi KM, Al-Zahrani A. The pattern of malocclusions in Saudi Arabian. patients attending for orthodontic treatment at the college of dentistry, King Saud. University, Riyadh. Saudi Dent J 1994; 6 (3): 138-44

9. Nur Avia Feroza, Fajar Kusuma Dwi Kurniawan, Diana Wibowo. Hubungan antara kebiasaan buruk bernafas melalui mulut dan tingkat keparahan maloklusi di smpn 4 banjar baru dan SMAN 4 banjarbaru.

10. Thomaz EBAF, Valenca AMG. Relationship between childhood underweight and dental crowding in deciduous teething. J Pediatria, 2009;85(2). DOI:10.1590/S002175572009000200005.

11. Staufer K, Landmesser H. Effects of crowding in the lower anterior segment-A risk evaluation depending upon the degree of crowding. J Orofac Orthop. 2004 Jan;65(1):13-25.

12. Isaac chour, Massler $M$. The development of the human dentition. J Am Dent Assoc 1941;28:115360.

13. Brito DI, Dias PF, Gleiser R. Prevalence of malocclusion in children aged 9 to 12 Years Old in the City of Nova. Friburgo, Rio de Janeiro State, Brazil. R Dent Press Ortodon Ortop Facial 2009;6(14):118-24.

14. Susilowati. Prevalensi maloklusi gigi anterior pada siswa Sekolah Dasar. Makassa Dent J 2016;5(3):97-101.

15. Tooth Eruption: The Primary teeth. J Am Dent Associat (JADA) 2005;(136):1619.

16. Pudjiadi S. Ilmu gizi klinis pada Anak. 4th ed. Jakarta: Universitas Indonesia. 2003.

17. Swarjana IK. Metodologi penelitian kesehatan. Yogyakarta:CV Andi Offset; 2015.

18. Waheed M. Dental crowding and its relationship to tooth size and arch dimension. Pakistan Oral \& Dent Jr. 2005;25(1) June: 47-52.

19. S Iswari Herlianti. Gigi Supernumerary dan Perawatan Ortodonsi. E Journal Widya Kesehatan dan Lingkungan Mei-Agustus 2013;1(1):37-45.

20. Pruthi N, Sogi MG, Fotedar S. Malocclusion and deleterious oral habits in a north indian adolescent population: A correlational study. Eur J Gen Dent 2013;2:257-63. 